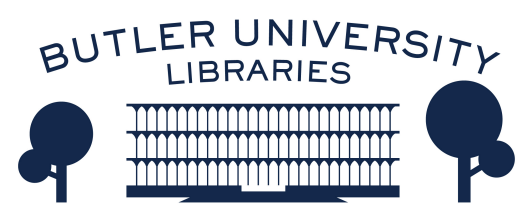

Journal of Hindu-Christian Studies

Volume 16

Article 8

January 2003

\title{
Advaita Vedanta and Marcus Borg: Opportunities for Hindu- Christian Dialogue
}

Anantanand Rambachan

Follow this and additional works at: https://digitalcommons.butler.edu/jhcs

Part of the Religion Commons

\section{Recommended Citation}

Rambachan, Anantanand (2003) "Advaita Vedanta and Marcus Borg: Opportunities for Hindu-Christian Dialogue," Journal of Hindu-Christian Studies: Vol. 16, Article 8.

Available at: https://doi.org/10.7825/2164-6279.1297

The Journal of Hindu-Christian Studies is a publication of the Society for Hindu-Christian Studies. The digital version is made available by Digital Commons @ Butler University. For questions about the Journal or the Society, please contact cbauman@butler.edu. For more information about Digital Commons @ Butler University, please contact digitalscholarship@butler.edu. 


\title{
Advaita Vedanta and Marcus Borg: Opportunities for Hindu-Christian Dialogue
}

\author{
Anantanand Rambachan \\ Saint Olaf College
}

DIALOGUE between Hindus and Christians in recent times appears to be dominated by the controversies concerning proselytizing and conversion. While these are important issues and ought not to be overlooked in Hindu-Christian interactions, we ignore, to our mutual deprivation, the wealth of insight about the nature of God and the meaning of being religious that are the fruits of reflection, practice and experience in our traditions. Our exploration of these issues reveal shared convictions, challenging questions for each other and the recognition that religious growth does not occur only through encounters within the boundaries of one's own religious world. While the Christian scholar, Marcus Borg, rarely refers to Hinduism in his writings, his interpretations of Christianity suggest exciting possibilities for dialogue between both traditions. This article is an attempt to identify, from an Advaita perspective, some of the potential issues for dialogue arising from Borg's work and a few questions that may be meaningfully raised and pursued. I am a listener to Borg's "Christian conversation" and offer these thoughts as an initial response.

In his well-know book, The God We Never Know, historian of religion Marcus Borg undertakes a critical assessment of certain central features of the Christian doctrine of God. ${ }^{1}$ According to Borg, one of the "root concepts" of God, present both in the Bible and in the wider Christian tradition, envisages the divine as a "supernatural being "out there," separate from the world, who created the world a long time ago and who may from time to time intervene within it." ${ }^{2}$ This "supernatural theism," as Borg terms it, is deeply anthropomorphic in its conception of God. As a person, God was separate from the world. Omnipresence meant that God, from the spatial remoteness of the heavens, knew everything or could choose to be in any place. The presence of God in the world was not continuous. Borg connects supernatural theism with the predominant influence of what he refers to as the "monarchical model of God." In addition to being patriarchcal, this model also emphasizes the distance, in terms of space and power, of God from the world. It prioritizes the role of God as judge and lawgiver and the religious life as consisting in essentially meeting the requirements of this remote God.

The supernatural theism that informed Borg's childhood image of God seemed inadequate as Borg encountered an enlightenment view that emphasized the reality of matter, natural laws, and the enormity of the universe. "The bigger the

\footnotetext{
Anantanand Rambachan teaches religion and philosophy at Saint Olaf College in Northfield, Minnesota, U.S.A. His scholarly interests include Advaita Vedanta, interreligious dialogue and Hinduism in the modern era. Among his books are The Limits of Scripture: Vivekananda's Reinterpretation of the Vedas (Honolulu: University of Hawaii Press, 1994) and Accomplishing the Accomplished: The Vedas as a Source of Valid Knowledge in Samkara (Honolulu: University of Hawaii Press, 1991). He is presently working on a contemporary reconstruction of Advaita.
} 
universe got, the farther away God seemed." The gap between a remote God and no God appeared insignificant. At the same time, Borg discovered that other Christian thinkers were wrestling with the inadequacies of supernatural theism. John Robinson rejected the view of God "out there" and argued for the encounter with the divine in the depths of the human being. Paul Tillich spoke of God as " the ground of being" or "ultimate reality" and sought to differentiate the nature of God's existence from objects in the world.

As an alternative to the intellectual and other difficulties presented by supernatural theism, Borg recovers what he believes to an alternative model of God, present both in the Bible and Christian tradition, but unfamiliar to most Christians. He refers to this way of thinking about the divine as panentheism, a model that understands God to be an allpervasive reality in which all things exist. It emphasizes God to be both immanent and transcendent. While all things exist in God (immanent), panentheism does not simplistically equate the world with God. God is much more than the universe (transcendent). God is always here and now. Many beautiful Biblical texts are adduced in support of panentheistic theology. Psalm 139 , for example, speaks of God as the allencompassing reality outside of which nothing exists.

You have searched me and known me;

You know when I sit down and when I rise up....

You go before me and behind me, And lay your hand upon me.... Where can I go from your Spirit? Or where can I flee from your presence?

If I ascend to heaven, you are there; And if I make my bed in Sheol, you are there.

If I take wings of the morning and settle

At the farthest limits of the sea,
Even there your hand shall lead me, And your right hand shall hold me fast. ${ }^{4}$

In Acts (17. 27-28), we have Paul's emphasis on the immediacy of God and his Tillich-like description, " They would search for God and perhaps grope for God and find God - though indeed God is not far from each one of us. For 'In God we live and move and have our being." "

Borg's panentheisitic way of thinking about God, acknowledging both immanence and transcendence, is heartily endorsed in the Advaita view of the nature of brahman. The universe is consistently described as existing in brahman even as brahman exists equally in everything. Taittiriya Upanisad (II.7.1) describes the bringing forth of the world from brahman and the latter's entry into everything created.

"He desired. Let me become many;
let me be born. He performed
austerity. Having performed
austerity, he created all this,
whatever is here. Having created it,
into it; indeed, he entered."

Isa Upanisad (1) opens with the famous exhortation to see the world clothed in God, " (Know that) all this, whatever moves in this moving world, is enveloped by God." It speaks of brahman as being within all things as well as outside of everything.

The existence of God in all and all in God is also a central theme in the Bhagavadgita, expressed both philosophically as well as poetically in similes and metaphors. One of the most striking of these (7:7) likens God to the string in a necklace of jewels. "On me," says Krishna, "all this universe is strung like jewels on a string." While the gems constituting a necklace differ in form and properties, the string that runs through each is one and the same. In an analogous way, God is the commion and unifying reality in all creation. Elsewhere (9:6) all beings are 
described as abiding and moving in God as the mighty wind exists and blows about in space. The significance of panentheistic theology in Hinduism may be appreciated also from the fact that seeing the divine existing equally in all beings is considered to be the hallmark of wisdom and liberation (13:28). The Bhagavadgita (18:20) commends the knowledge that enables us to see "one imperishable Being in all beings, undivided in separate beings." A false and inferior way of seeing is to regard things as isolated, separate and independent of each other and to see in all beings "separate entities of various kinds (18:21).",

The Advaita Vedanta tradition will also want, like Borg, to differentiate between panenthiesm and pantheism. ${ }^{8}$ Although the Hindu doctrine of God is often represented as pantheistic, immanence is never emphasized at the expense of transcendence. The language of paradox is commonly used to remind us of God's mystery and indefinable nature. Isa Upanisad (4-5) is one of the finest examples of this method.

(The spirit) is unmoving, one, swifter than the mind. The senses do not reach It as It is ever ahead of them. Though Itself standing still It outstrips those who run. In It the allpervading air supports the activities of beings.

It moves and It moves not; It is far and It is near; it is within all this and It is also outside all this.

Bhagavadgita (13:15-17) echoes the Isa Upanisad and describes brahman as undivided, though appearing divided, outside and inside beings, far away and near. Katha Upanisad (II.2.9-II.2.11), after explaining the existence of brahman within all, turns to the example of the sun to underline its transcendence. The sun, which helps all eyes to see, is not affected by the defects of the eyes or external objects. Similarly, brahman, existing within all beings, is not tainted by the defects of the world as "He is outside."

The Advaita tradition, however, does not stop with the characterization of the divine-world relationship as one of panentheism. While able to agree with Borg's representation God as "a nonmaterial layer or level or dimension of reality," pervading all things, the tradition wishes to characterize further the relationship between the nonmaterial and material as not-two (advaita). Describing the relationship between-brahman and the world as advaita must, however, also be differentiated from pantheism. Sankara, it should be noted, does not entirely equate the world with brahman. For Sankara, the fact that brahman is described as the cause and the world as the effect implies some difference. If no differences obtain, the distinction would be meaningless.

As between cause and effect, some distinction has got to be admitted as existing, as in the case of clay and a pot, for unless some peculiarity exists, it is not possible to distinguish them as cause and effect. $^{9}$

What the characterization of the brahman-world relationship as advaita does deny is the independent ontological reality of the world from brahman. The world does not have a reality that is independent of brahman. The reality of the world is a dependent one, whereas brahman's reality and nature is independent and original. "The effect," as Sankara puts it, "has the nature of the cause and not vice-versa. ${ }^{10}$ While the world partakes of the nature of brahman, brahman does not partake of the nature of the world. Is an Advaita tradition, constructed along these lines and so clearly differentiated from pantheism, compatible with the Christian panentheism of Borg? Is it necessary for the panentheist to clarify further the relationship between the world and God and, if so, what are the problems 
and promises of describing this in Advaita terms? Borg's panentheism, it appears to me, invites further conversation along these lines, and Advaita will be a willing partner. The movement from supernatural theism to panentheism results also, according to Borg, in a different understanding of the fundamental human problem. When supernatural theism is fused with a monarchical image of God, a performance model is generated that emphasizes "meeting requirements," sin and guilt." Panentheism, on the other hand, which understands God to be a nonmaterial reality, present in and transcending the universe, sees the human problem in terms of estrangement and separation. In Borg's words, it is "our blindness to the presence of God, our separation from the Spirit who is all around us and within us and to which we belong."12 Whether we know it or not, we exist in and are inseparable from God. We are not spatially, but epistemologically distant from God.

Borg's implicative redefinition of the human condition presents it in terms that appear to relate closely to the Advaita understanding of the human problem as one of ignorance (avidya). For Sankara, brahman, as a reality unlimited by space or time, is always present and immediately available. It is here and now. Sankara, however, goes beyond this and argues that the existence of brahman does not have to be established by any means of knowledge since, as awareness, the ground of all mental and perceptual processes, it is self-revealing. In his commentary on Brahma-sutra (1.1.1), Sankara has an objector asking if brahman is known or unknown. The issue here is that if Sankara admits brahman to be known, there will be no need for any inquiry or a means of knowledge to determine its nature and Sankara is, in fact, arguing for both of these. If on the other hand, brahman is unknown (not even the object of a desire to know), it cannot become the focus of any sort of inquiry. One must be aware of an object, at least in some minimal way, to want to inquire further. Sankara evades the philosophical clutches of Scylla and Charybdis by arguing that brahman is not entirely unknown. It is self-revealing as the ground and content of the " $T$ " notion and is the source of the conviction that one exists. ${ }^{13}$

Besides, the existence of brahman is well known from the fact of Its being the Self of all; for everyone feels that his Self exists, and he never feels 'I do not exist.' Had there been no general recognition of the existence of the Self, everyone would have felt, 'I do not exist.'

The religious challenge, therefore, is not one of creating or bringing into existence a previously non-existent entity, or bridging a spatial or temporal distance between oneself and God. Avidya may be likened to a form of blindness that prevents us from properly seeing what is right before our eyes and its overcoming, which is the attainment of liberation (moksha), akin to the regaining of sight. Liberation, to use Borg's words, is the overcoming of our "epistemic distance" from God, since no other kind of separation from an infinite reality is possible. As Sankara puts it in his Brahma-sutra (1.1.4) commentary, "Brahman, being all-pervasive like space, remains ever attained by everybody."

The Advaita understanding of the nature of brahman as available here and now and of the human condition as essentially one of ignorance (avidya) leads to an emphasis on liberation (moksha) as a way of being in this life. ${ }^{14}$ Liberation is not an end that must await the death of the body since the human problem is not synonymous with the fact of being alive but with ignorance (avidya) of brahman. It is not the absence of a body that constitutes liberation, but the overcoming of ignorance about brahman. The state of living liberation is referred to as jivanmukti and the person is called a jivanmukta. Shankara clearly supports the idea of embodied liberation. In his remarks on 
Katha Upanisad (2.1.2), for example, he comments on the fearlessness of the liberated person. "How can there be any vision of fear, since there is no occasion for sorrow after the attainment of fearlessness from His realization? Even here, (while still living), he becomes vimuktah, free." $\mathrm{He}$ interprets Katha Upanisad (2.2.14), ("He attains brahman here') to mean the discovery of one's non-difference with brahman while still living. ${ }^{15}$

It is interesting that Borg's description of the human condition as an epistemological separation from God leads also to an emphasis on salvation as a concern of life in this world and not as an exclusive post-mortem hope or state. Commenting on John (17:3) "This is eternal life: to know God," Borg notes that "eternal life" is not simply or primarily in the future but is a present reality. To know God is already an experience of "eternal life." Salvation implies an awakening to the reality of God in oneself, the world and others. The gain of eternal life, in this world, through the attainment of moksha, is a constant theme of the Upanishads and the Advaita tradition. Brhadaranyaka Upanisad (4.4.6-7), for example, speaks of attaining immortality in this world:

On this there is the following verse: "When all the desires that dwell in the heart are cast away, then does the mortal become immortal, then he attains brahman here (in this very body)."

Sankara, while conceding that the word svarga is generally used to indicate a heavenly region or place, notes that there are contexts when svarga refers to liberation. ${ }^{17}$ Commenting on the reference to svarge loke in Kena Upanisad (4.9) Sankara interprets it as referring to brahman. Being qualified by the words ananta (infinite) and jyeye (highest), svarga does not refer to heaven, but to brahman that is infinite and higher than all else. In other words, the attainment of brahman must be differentiated from the post-mortem journey to another world.

Borg's ability to speak of salvation as a way of being in the present life and " not about believing now or being good now for the sake of heaven later," enables him to identify what he calls "the gifts of salvation." Citing Paul, Borg identifies freedom, peace, joy and love as four of the central gifts. Borg describes salvation as an experience " of the sheer joy of being, just as we experience the sheer joy of being reconciled to ourselves, to each other, and to life itself. We experience the joy of being loved and the ability to love in the freedom and self-forgetfulness of faith." 18

Similarly, while the Upanisads are hesitant to characterize the actual state of moksha, which being identical with brahman, defies all definition, the texts are not as reticent about the liberated person (jivanmukta). Positively, liberation is the attainment of bliss since bliss constitutes the very nature of brahman. When Bhrgu, in the Taittiriya Upanisad (3.6.1) finally understood brahman, he understood it as the bliss from which all things are born, by which they are sustained and into which they return. Commenting on this verse, Sankara explains that one who comes to know brahman as bliss, "gets similarly fixed in bliss that is the supreme brahman; that is to say, be becomes brahman itself." Brahman, states Brhadaranyana Upanisad (4.3.32) is supreme bliss. "On a particle of this very bliss other creatures live." In the Chandogya Upanisad (7.1.13) Narada goes to his teacher, Sanatkumara, for knowledge of the self that frees from sorrow and learns that the infinite alone is bliss; there is no bliss in the finite.

Liberation is also equated, especially, in the Bhagavadgita with the attainment of peace (shanti). It is the person who overcomes greed and not the one who is a victim of greed who obtains peace (2:7071). The attainment of brahman is possible for the person with faith (shraddha) and the consequence of understanding is the 
realization of peace (4:93). Katha Upanisad (1.3.13) speaks of the atman as peaceful (shanta) and of eternal peace for those who discover the self within (2.2.13). ${ }^{19}$

Liberation for Borg is also the overcoming of estrangement and reunion "with the world and with the one in whom we and the world live and move and have our being." 20 Although the language of estrangement is not employed in traditional Advaita discourse, liberation as the overcoming of estrangement is clearly implied in the Advaitta understanding that the knower of brahman apprehends it, not merely as her own self, but as the self of all. The knower of the self, according to the Bhagavadgita (6:29) sees the self in all beings and all beings in the self. Isa Upanisad (6) relates the knowledge of the oneness of the self to freedom from hate.

One who sees all beings in the self alone and the self in all beings, feels no hatred by virtue of that understanding.

For Marcus Borg, the most important fruit of awakening to God is compassion. It is the "central test for discerning whether something is 'of God.' 21" Compassion, however, is not merely a private, individual virtue. It is not about "how to be good and how to behave within the framework of a domination system." 22 Compassion is the concern and effort to replace unjust and oppressive social structures with a "domination-free order." Its focus is on the removal of suffering, arising from exploitative political, economic and social structures. It is here that Borg's understanding of the meaning of liberation presents its most radical challenge to traditional Advaita Vedanta.

It is indeed true, as Andrew Fort has observed, that traditional Advaita has not concerned itself with equality in the social spheres. ${ }^{23}$ Sankara's comments on Bhagavadgita (6:32) and Isa Upanisad (6), for example, emphasize freedom from hate and abstention from causing harm to others rather than love and engagement in action for the alleviation of suffering. The implications of the truth of the unity of self are interpreted passively. He seems also to limit the Bhagavadgita doctrine of loka samgraha (the welfare of the world) to the teaching role of the jivanmukta, who acts out of compassion for the suffering of the student. Sankara's emphasis on the teaching role of the jivanmukta ought to be seen in the light of the Advaita emphasis on selfignorance as the root of suffering and on the assumption that jivanmuktas may be few in number. If, however, the jivanmukta is motivated to teach because of compassion for the suffering of the student, there is no good reason why other kinds of action, similarly, motivated by compassion for the suffering, are not possible. While the social involvement of the jivanmukta in activities that go beyond teaching is not a traditional Advaita position, the question today is whether such involvement is desirable and if the Advaita understanding of liberation allows for. My position is affirmative on both questions, but the scope of this study only allows me to present elements of it in brief form.

Although the Hindu scriptures, because of veneration for the jivanmukta, do not prescribe any obligatory actions, there is nothing inherent in the liberated state that makes actions for the well being of others impossible. On the contrary, the understanding of the self and reality that is synonymous with the attainment of liberation provide a powerful justification and impetus for a life of compassion and social engagement. Freedom from avidyagenerated desires does not eradicate every form of motivation to engage in action. Liberation from self-centered desires frees one to dedicate one's energies to the service of others. This may be the point of Bhagavadgita (3:22-24) where Krishna uses himself as an example of a liberated being with no personal desires who engages in action for the benefit of others. He suggests 
(3:25) that the liberated person can bring the same energy and enthusiasm to working for others that the unliberated person brings to the quest for personal goals. Sankara concurs with Krishna's views that freedom from personal desires makes actions on behalf of others possible and paraphrases Krishna's meaning in 3:25 as follows: "For Me or for any other person who, knowing the Self, thus seeks the welfare of the world, there is nothing to do except it be with the a view to the welfare of the world at large."

The knowledge of the indivisibility of the self, properly understood, awakens a deeper identity and affinity with all. Moksha does not alienate one from the community of other beings, but awakens one to the truth of life's unity and interrelatedness. While the Upanisads and the classical Advaita tradition do not pursue the implications of this understanding for the life of the jivanmukta in society, there is no reason why we should not do so today. In the Bhagavadgita, the discussion on the identity of the self in everything is followed by a verse (6:32) that praises the highest yogi as the one who, because of knowing the truth of brahman, owns the pain and suffering of others as her own. In his comment on this verse, Sankara writes that this person "sees that whatever is pleasant to himself is pleasant to all creatures and whatever is painful to himself is painful to all beings. Thus seeing that what is pleasure or pain to himself is alike pleasure and pain to all beings, he causes pain to no being; he is harmless. Doing no harm and devoted to right knowledge, he is regarded as the highest among all yogins. ${ }^{, 24}$

If knowledge of the identity of the self in all leads, as the Bhagavadgita puts it, to seeing the suffering of another as one's own, undertaking actions for the alleviation of suffering, whenever possible, becomes necessary. Seeing the suffering of the other as one's own seems rather meaningless if this insight does not instigate action on behalf of the other. While recognizing avidya to be the fundamental cause of suffering, one ought not to ignore the suffering that human beings experience when they lack the opportunities to attain the necessities for decent living such as food, housing, clean water, health care and literacy or when suffering is inflicted through injustice and oppression based on gender, caste or race. We need to question the broad significance and meaning of the ideal of moksa for human relationships and for social, economic and political relationships. It should not be acceptable to affirm truths about the unity of the self and discerning one's self in all while tolerating injustice and indignity at the social level.

The vision of brahman in all beings is a truth with the potential to help us overcome alienation and estrangement in a world in which technology has made us aware of each other as never before. It enables us to identify with others beyond the boundaries of our nationality, ethnicity, tribe and religion, to share their suffering and rejoice in their successes. It helps us to see human beings as constituting a single community and provides a philosophical basis for a compassionate and inclusive community where the worth and dignity of every human being is affirmed and where justice, at all levels, is sought. This will not occur, however, until the Advaita tradition positively asserts the value of the world and human existence within it, the importance of reconciling religious claims and social reality and the necessity of working to transform the latter in the light of the former. Dialogue with Christianity and other religions can be a great asset to Advaita in becoming aware of and in responding creatively to these challenges.

\section{Notes}

1. See Marcus Borg, The God We Never Knew (New York, NY: HarperCollins, 1997).

2. Ibid., p. 11.

3. Ibid., pp. 62-71. 
4. Quoted in The God We Never Knew, pp. 35-36.

5. The Principal Upanisads, ed. and trans. S. Radhakrishnan (London, England: Allen and Unwin, 1953).

6. The Bhagavadgita, trans. Winthrop Sargeant (Albany, NY: State University of New York Press, 1993).

7. See also 6:30-32; 18:61.

8. The God We Never Knew, pp. 32-33.

9. Brahma-sutra-bhasya of Sankaracarya, trans. Swami Gambhirananda (Calcutta: Advaita Ashrama, 1977) 2.2.44.

10. Tbid., 2.1.9

11. The God We Never Knew, pp. 65-68.

12. Ibid., p. 77.

13. For a discussion of the relationship between the nature of the self and the appropriate means of knowledge see, Anantanand Rambachan, Accomplishing the Acomplished: The Vedas as a Source of Valid Knowledge in Sankara (Honolulu, HI: University of Hawaii Press, 1991).

14. Moksha does have postmortem implications in Advaita, such as freedom from the cycle of birth, death and rebirth (samsara). These consequences, however, flow from its attainment in life.
15. Eight Upanisads: with the commentary of Sankaracarya, trans. Swami Gambhirananda [Isa, Kena, Katha, and Taittiriya in vol.I; Aitareya, Mundaka, Mandukya and Karika, and Prasna in vol.II] (Calcutta: Advaita Ashrama, 1965-66).

16. The God We Never Knew, pp. 165.

17. Brahma-sutra bhasya 4.4.8.

18. The God We Never Knew, pp. 167.

19. See also Taittiriya Upanisad (1.6.2) that speaks of brahman as abounding in peace.

20. The God We Never Knew, p. 167

21. Ibid., p. 129.

22. Ibid., p. 142

23. See Andrew O.Fort, Jivanmukti in Transformation (Albany, NY: State University of New York Press, 1998), p. 174

24. The Bhagavadgita with the Commentary of Sankaracarya, trans. A. Mahadeva Sastry (Madras: Samata Books, 1977). 